\title{
Fiscal equalization as a driver of tax increases: empirical evidence from Germany
}

\author{
Thiess Buettner $^{1}$ D $\cdot$ Manuela Krause ${ }^{2}$
}

Published online: 30 June 2020

(c) The Author(s) 2020

\begin{abstract}
This paper exploits the devolution of taxing powers in the German federation to study the effects of fiscal equalization on subnational governments' tax policy. Based on an analysis of the system of fiscal equalization transfers, we argue that the redistribution of revenues provides incentives for states to raise rather than to lower their tax rates. The empirical analysis exploits differences in fiscal redistribution among the states and over time. Using a comprehensive simulation model, the paper computes the tax-policy incentives faced by each state over the years and explores their empirical effects on tax policy. The results support a robust and strong incentive effect that works through the tax-base. When facing full equalization, a state is predicted to set the rate of the real estate transfer tax at about 1.3 percentage points higher than without. Our analysis also shows that the incentive to raise tax rates has proliferated because individual states' decisions to raise their tax rates have intensified fiscal redistribution over time.
\end{abstract}

Keywords Fiscal equalization - Tax autonomy $\cdot$ Real estate transfer tax $\cdot$ Tax capacity $\cdot$ Standard tax rate

JEL Classification $\mathrm{H} 20 \cdot \mathrm{H} 26 \cdot \mathrm{R} 38$

The authors would like to thank Niklas Potrafke, Willem Sas and seminar participants at various workshops and conferences for their helpful suggestions and comments as well as Tobias Goerbert for his excellent research assistance.

Thiess Buettner

thiess.buettner@fau.de

Manuela Krause

krause@iwkoeln.de

1 FAU and CESifo, Friedrich-Alexander-University Erlangen-Nuremberg, Lange Gasse 20, 90403 Nuremberg, Germany

2 German Economic Institute, Konrad-Adenauer-Ufer 21, 50668 Cologne, Germany 


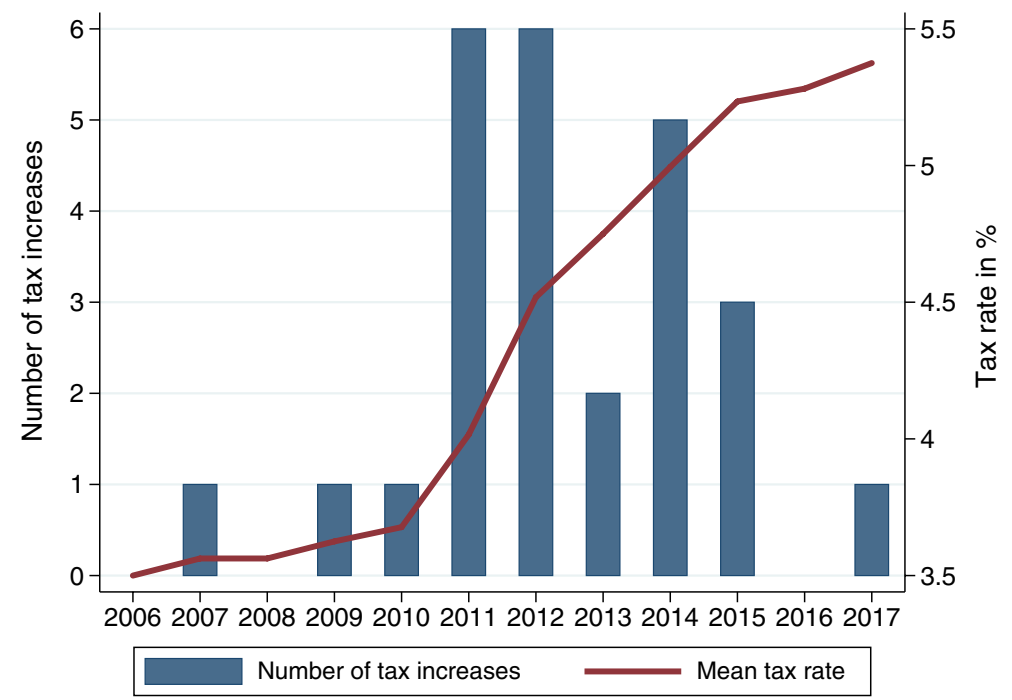

Fig. 1 Real estate transfer tax rate increases among the German States. Number of tax rate increases by the 16 German states in the years after the 2006 reform (left axis) and unweighted tax-rate average (right axis) by year. In 2006, all states were required to charge a tax rate of 3.5\%. The authors' own calculations

\section{Introduction}

A key characteristic of federations is the fiscal autonomy of subnational governments. This includes the discretion to decide about expenditures and to impose local taxes. This autonomy is often combined with equalization transfers ensuring that all subnational governments have sufficient funding to provide a similar level of public good provision. As Boadway (2004, p. 212) puts it “...equalization can be seen as a necessary counterpart to decentralization, offsetting its tendency to create disparities among regions in the ability to provide public goods and services." However, since fiscal equalization provides jurisdictions with more funds when their own revenues decline, fiscal equalization may alter the incentives of subnational governments to raise their own source revenues. In particular, states receiving transfers may reduce their own tax effort (e.g., Musgrave 1961). Yet, depending on how fiscal equalization is designed, it may provide incentives to increase rather than lower taxes (e.g., Smart 1998).

In a reform that became effective in 2007, the German federation has aimed to strengthen the autonomy of state governments in taxation and assigned the rate of the real estate transfer tax (RETT) to the discretion of the states. The system of fiscal equalization was left basically unchanged, however. As depicted in Fig. 1, the reform in 2006 had strong effects on tax policy. In the decade following the reform, the 16 German states have enacted no less than 26 tax rate changes. All changes were tax increases-no state has lowered its tax rate. Initially, the tax rate was $3.5 \%$ on the sales price. In some states, the tax rate has almost doubled; in 2017 , the mean tax rate reached a level of $5.3 \%$. 
The economic literature suggests that the RETT is a rather distortionary tax instrument. Because the tax drives a wedge between the buyer's and the seller's price, real estate transactions are deterred and the matching efficiency on real estate and labor markets is adversely affected (e.g. Lundborg and Skedinger 1999; Adam et al. 2011; Dachis et al. 2011). The fact that the states have utilized this distortionary tax instrument so heavily may indicate that they are under substantial revenue stress. Krause and Potrafke (2019) argue that the tax increases can partially be explained by government ideology as states with increasing rates differ in the party affiliation of government. As we show in this paper, an alternative explanation is that, rather than simply depressing the states' efforts to raise their own source revenues, the combination of tax autonomy and fiscal equalization in Germany actually provides strong incentives to raise the local tax rates.

The incentives of subnational governments for tax policy are the subject of a large body of theoretical literature (for surveys see Wilson 1999; Keen and Konrad 2013). This literature has emphasized in particular that tax policy of individual governments exerts fiscal externalities on others. If the set of tax instruments is restricted, the resulting tax competition equilibrium is typically characterized by inefficiently low tax rates. The literature has also noted that federal countries have institutions that work in the opposite direction (Keen and Kotsogiannis 2002). In particular, the literature has pointed to the role of fiscal redistribution (e.g. Smart 1998; Koethenbuerger 2002; Bucovetsky and Smart 2006). More specifically, the focus of the theoretical literature is on the incentives of a specific type of fiscal redistribution implemented by the Australian, the Canadian, the German as well as the Swiss federations. These countries feature systems of fiscal capacity equalization, where fiscal transfers are a function of fiscal capacity. With fiscal capacity equalization, the adverse impact of a high tax rate on the tax base, which reflects the deadweight loss from taxation, depresses the fiscal capacity of the state. Because this results in higher equalization transfers, states tend to disregard the economic cost of taxation and are subject to an incentive to increase their local tax rates.

The empirical literature on the tax policy incentives of fiscal capacity equalization is relatively scarce. Dahlby and Warren (2003) analyze the effects of fiscal equalization on the incentive of Australian states and territories to raise taxes and note that states that receive more transfers when raising taxes actually tend to impose higher taxes. Evidence for Canada is provided by Smart (2007), who uses an instrumental-variable approach to find that tax rates in grant-receiving provinces are higher and more responsive to the tax rate in other provinces. More recently, Ferede (2017) considers the effects of equalization on provincial business and personal income tax rates in Canada. As in Dahlby and Warren (2003), the analysis distinguishes between an incentive that works through the effect of tax policies on the provincial tax base and an incentive that works through the effects on the average (representative) tax rate used to determine fiscal capacity. To identify the effects for grant-receiving provinces, Ferede (2017) exploits the discontinuity in the grant allocation formula. The results show that equalization leads to higher tax rates, in particular to higher personal income tax rates.

Despite the strong fiscal redistribution present in the German federation, there are no papers providing evidence on incentive effects exerted on the German states' tax 
policy. This is, of course, the consequence of the lack of tax autonomy that characterized German states before the reform. Baretti et al. (2002) as well as Boenke et al. (2015) explore effects of fiscal redistribution on tax collection efforts.

Empirical research has also explored effects of redistributive state grants to German municipalities (e.g. Buettner 2006; Egger et al. 2010; Rauch and Hummel 2016). While this research generally supports causal effects on local tax policy, the mechanism behind the policy response differs slightly from fiscal capacity equalization. As noted by Dahlby and Warren (2003), in systems of fiscal capacity equalization, the degree of redistribution faced by a jurisdiction is directly affected by tax policy. More specifically, if jurisdictions raise their tax rate, the average (representative) tax rate increases. As a consequence, fiscal capacity equalization may exert much stronger effects on tax policy than redistributive grants to municipalities.

This paper contributes to the empirical literature on tax policy effects of fiscal equalization by exploring the tax policy of German states. By considering the period following the devolution of tax setting powers, the German case provides ideal conditions to study how the tax policy incentives from equalization affect subnational tax policy and how these incentives change as a result of changes of tax policy. In order to measure the specific tax policy incentive faced by each state, we implement a detailed simulation model of the equalization system, which comprehensively captures the development of incentives in all states over the observation period. The model provides indicators of the degree of fiscal redistribution and the fiscal position of each state over time, which enable us to distinguish income effects associated with equalization from its incentive effects. Since the degree of fiscal redistribution faced by the individual state partly depends on its own tax policy and revenues, we employ instrumental variables based on simulations that keep a state's tax rate and its share of the tax base at pre-reform levels. Controlling for the fiscal position and the associated income effects, the results support a substantial effect of fiscal equalization on a state's tax policy. According to the estimates, with full equalization states set their tax rates from the real estate transfer tax at about 1.3 percentage points higher than without. Our analysis also shows that the incentive to raise tax rates has proliferated as each state's decision to raise its tax rate has increased the incentive to raise taxes for all other states.

The following section derives empirical predictions using a theoretical analysis of tax policy incentives under fiscal capacity equalization. Subsequently, Sect. 3 discusses the empirical methodology and Sect. 4 describes the data. Section 5 presents the results. Section 6 concludes.

\section{Tax policy under fiscal capacity equalization}

This section provides a stylized analysis of optimal tax policy in the presence of fiscal capacity equalization. For simplicity, the revenues $R_{i}$ of a state $i$ are assumed to consist of three components

$$
R_{i}=T_{i}+\tau_{i} B_{i}+Z_{i}
$$


One component is revenue from shared taxes $T_{i}$, the second component is revenue from the local tax and the third component is a fiscal transfer.

A capacity-based fiscal equalization scheme defines the transfers using a function of the relative fiscal position $S_{i}$ of state $i$

$$
Z_{i}=Z\left(S_{i}\right), \quad \text { where } Z_{i}^{\prime}<0 \text { and }\left\{\begin{array}{l}
Z_{i}>0 \text { if } S_{i}<1 \\
Z_{i}=0 \text { if } S_{i}=1 \\
Z_{i}<0 \text { if } S_{i}>1
\end{array}\right.
$$

The relative fiscal position is defined as

$$
S_{i}=\frac{C_{i}}{\frac{1}{n} \sum C_{j}},
$$

which relates the fiscal capacity $C_{i}$ of state $i$ to the average capacity in all $n$ states. Hence, the transfer is positive if capacity is below $\left(S_{i}<1\right)$ and negative if capacity is above average $\left(S_{i}>1\right)$.

Fiscal capacity is defined as

$$
C_{i}=T_{i}+\bar{\tau} B_{i}
$$

where $\bar{\tau} B_{i}$ is standardized revenue from a local tax with $B_{i}$ denoting the taxable base and $\bar{\tau}$ denoting the weighted average of tax rates

$$
\bar{\tau}=\frac{\sum \tau_{j} B_{j}}{\sum B_{j}} .
$$

Function $Z_{i}$ is strictly decreasing in $S_{i}$ and has zero value at $S_{i}=1$. This implies that a state, that receives transfers $\left(S_{i}<1, Z_{i}>0\right)$, experiences a decrease in transfers if the relative fiscal position $S_{i}$ increases. ${ }^{1}$

In a purely redistributive system, the sum of transfers $\sum Z_{j}$ would be equal to zero. In the terminology of Boadway (2004), such a system would be a "net scheme." However, given the German institutional setting, we focus on a "gross scheme". 2 To simplify the discussion of tax policy under fiscal equalization, we assume that the tax base in one state is unaffected by the local tax rate in other states $\frac{\partial B_{j}}{\partial \tau_{i}}=0$. Hence, there are no direct tax externalities.

\footnotetext{
${ }^{1}$ The function $Z(S)$ may well be discontinuous. In the German case, the derivative of the function is discontinuous, i.e. there exist threshold levels $\sigma$ such that $\lim _{S_{i} \rightarrow \sigma^{-}} Z^{\prime}\left(S_{i}\right) \neq \lim _{S_{i} \rightarrow \sigma^{+}} Z^{\prime}\left(S_{i}\right)$. For the discontinuity in the Canadian system see Ferede (2017).

${ }^{2}$ Fiscal equalization in Germany is based on a gross scheme as the resources needed to fund the equalization system are provided residually by the federal government. Depending on how the federal government is funded, a change in federal transfers still has effects on the tax payers in the state. Ultimately, this may also affect tax policy in state $i$. However, for simplicity, we abstract from those effects in the theoretical analysis.
} 
With these simplifications, the effect of an increase in the state's own tax rate on total revenues is

$$
\frac{\partial R_{i}}{\partial \tau_{i}}=B_{i}+\tau_{i} \frac{\partial B_{i}}{\partial \tau_{i}}+Z^{\prime}\left(S_{i}\right) \frac{\partial S_{i}}{\partial \bar{\tau}}\left(\frac{B_{i}}{\sum B_{i}}\right)+Z^{\prime}\left(S_{i}\right) \frac{\partial S_{i}}{\partial B_{i}} \frac{\partial B_{i}}{\partial \tau_{i}},
$$

where the first two terms reflect direct ("mechanical") and indirect effects on tax revenues and the other two terms capture the change in transfers due to changes in fiscal capacity $S_{i}$. Denoting the tax-rate elasticity of the taxable base with $\eta_{i}$ allows the equation to be simplified

$$
\frac{\partial R_{i}}{\partial \tau_{i}}=B_{i}\left(1+\rho_{i}\right)-B_{i} \eta_{i}\left(1-\beta_{i}\right) .
$$

The effect of fiscal equalization is captured by two parameters: $\beta_{i}$ and $\rho_{i}$. $\beta_{i}$ is a measure of fiscal redistribution of a change in revenues due to a change in the tax base. Formally defined as

$$
\beta_{i}=-\left(Z^{\prime}\left(S_{i}\right) \frac{\partial S_{i}}{\partial B_{i}} / \tau_{i}\right)>0,
$$

it captures the fraction of an increase in revenues due to a higher tax base that is compensated for through lower transfers. This effect has been dubbed equalization base effect (Dahlby and Warren 2003). To illustrate the intuition, consider a state that receives a transfer $Z_{i}>0 .{ }^{3}$ Since the relative fiscal position increases with the tax base, $-Z^{\prime}\left(S_{i}\right) \frac{\partial S_{i}}{\partial B_{i}}$ determines the loss in transfers given an increase in the tax base. Dividing this loss in transfers by the tax rate relates the change in revenues to the direct revenue effect from an increase in the tax base. If $\beta_{i}$ is close to zero, a higher tax base has little impact on transfers and the revenue gain from an increase in the tax base is mainly kept by the state. If $\beta_{i}$ is close to unity, a higher tax base results in a strong decline in fiscal transfers. In this case, the net revenue impact of an increase in the tax base is small. If $\beta_{i}$ exceeds unity, a higher tax base would result in net-revenue losses. While such heavy redistribution seems hard to justify, it can not be ruled out for practical applications.

With regard to the revenue effect of a tax rate increase in (2), $\beta_{i}$ tends to reduce the revenue implication of the adverse effect of higher taxes on the tax base. As a consequence, the higher the value of $\beta_{i}$, the larger is the (net-)revenue gain from higher taxes.

The second parameter characterizing fiscal equalization, $\rho_{i}$, is a measure of fiscal redistribution of a change in revenues due to the tax rate at a given tax base. Dahlby and Warren (2003) call this the equalization rate effect. Formally defined as

\footnotetext{
3 If the state is a net contributor $\left(Z_{i}<0\right)$, an increase in the tax base is associated with a higher contribution. In this case $\beta_{i}$ measures the extent to which a revenue increase due to a higher tax base is compensated for by higher contributions.
} 


$$
\rho_{i}=\left(Z^{\prime}\left(S_{i}\right) \frac{\partial S_{i}}{\partial \bar{\tau}}\left(\frac{B_{i}}{\sum B_{j}}\right) / B_{i}\right),
$$

it captures the fraction of an increase in revenues due to a higher tax rate at a given tax base that is compensated for through lower transfers. The effect of the local tax rate on the average (representative) tax rate at a given tax base is determined by the share in the total tax base $\left(\frac{B_{i}}{\sum B_{j}}\right)$. Hence, any increase in the tax rate raises the average tax rate. However, whether this contributes to an increase in the relative fiscal capacity or not depends on the state's shares of fiscal capacity and tax base. ${ }^{4}$ The parameter $\rho_{i}$ scales the effect on transfers with the actual tax base $B_{i}$ in order to relate the change in revenues from transfers to the mechanical revenue effect of an increase in the tax rate.

If $\rho_{i}$ is close to zero, a higher tax rate has little direct impact on transfers and the mechanical revenue gain from an increase in the tax rate at a given tax base is mainly kept by the state. If $\rho_{i}$ is positive (negative), the net revenue impact of an increase in the tax rate at a given tax base is larger (smaller) than the mechanical revenue gain.

To discuss the implications of fiscal equalization for tax policy, we consider the marginal cost of public funds ${ }^{5}$

$$
M C F_{i}=B_{i}\left(\frac{\partial R_{i}}{\partial \tau_{i}}\right)^{-1}=\frac{1}{\left(1+\rho_{i}\right)-\eta_{i}\left(1-\beta_{i}\right)} .
$$

In the absence of fiscal redistribution, $\beta_{i}=0, \rho_{i}=0$, the marginal cost of funds is simply an increasing function of the elasticity of the base. With fiscal redistribution, $\beta_{i}>0$ and the marginal cost of funds is reduced. This provides an incentive to expand public consumption and to increase tax rates. With $\beta_{i}=1$ and $\rho_{i}=0$, the marginal cost of funds would be unity. In this case, the tax would effectively be perceived as a lump-sum tax. If $\beta_{i}>1$, the marginal cost of funds may even be smaller than unity. If the equalization rate effect $\rho_{i}$ is positive, the marginal cost of funds declines. This is intuitive since a tax rate increase would then weaken the fiscal position and more fiscal transfers are obtained.

In the above setting, even if there are no direct tax externalities, the transfers depend on the tax policy decisions in other states: the relative fiscal position and the

\footnotetext{
4 Note that

$$
\frac{\partial S_{i}}{\partial \bar{\tau}}=S_{i} \frac{B_{i}}{C_{i}}\left[1-\frac{C_{i}}{\sum_{j} C_{j}} / \frac{B_{i}}{\sum_{j} B_{j}}\right] .
$$

The effect is positive, if a state with a large share of the tax base has a relatively small share of fiscal capacity. In this case, the fiscal position of the state increases when the average tax rate rises $\frac{\partial S_{i}}{\partial \bar{\tau}}<0$. As this increase results in lower transfers, $\rho_{i}$ would be negative.

5 Note that we discuss the marginal cost of public funds from the perspective of a state government. The perspective of the federation might be different, see Wildasin (1989).
} 
average tax rate both depend on the tax rates and tax bases in all other states. Hence, the parameters $\rho_{i}$ and $\beta_{i}$ vary with tax policy in other states.

\section{Empirical methodology}

In the empirical analysis, we consider the states' tax policies after a federal reform that granted the states the right to determine the local rate of the real estate transfer $\operatorname{tax}$ (RETT). The analysis exploits the fact that the degree of fiscal redistribution differs among the states and over time.

The empirical analysis focuses on the choice of the tax rate. Basically, it is concerned with the relationship between the change of the tax rate and precise indicators of fiscal redistribution. This includes the degree of fiscal redistribution associated with tax base $\beta_{i}$ and tax rate $\rho_{i}$. Based on the theoretical discussion, we assume that if the degree of fiscal distribution is high, a state is more likely to increase its tax rate. Since the tax policy is required to set the tax rate in advance, state governments base their tax decisions for the upcoming period on the realization of fiscal capacity and on the realized degree of fiscal redistribution. ${ }^{6}$ This suggests that the following specification should be used

$$
\Delta \tau_{i, t+1}=\alpha_{i}+b_{1} \beta_{i, t}+b_{2} \rho_{i, t}+\sum_{j=1}^{p} b_{3, j} S_{i, t}^{p}+\gamma_{t}+\varepsilon_{i, t} .
$$

where $\alpha_{i}$ is a fixed state effect and $\gamma_{t}$ is a fixed time effect for period $t$. The latter captures common trends in the German federation. $b_{1}$ and $b_{2}$ capture the effects of fiscal redistribution. In the light of the above analysis, positive coefficients are expected because the marginal cost of funds is reduced when $\beta_{i}$ and $\rho_{i}$ increase.

The identification strategy utilizes the fact that the equalization transfers are formula based and are determined by a smooth function of relative fiscal capacity. By allowing for arbitrary non-linear effects of the assignment variable $S_{i, t}^{p}$, the estimation approach ensures that only differences in the degree of fiscal redistribution conditional on the fiscal position of a state are used to identify the incentive effects of fiscal equalization. Thereby, we make sure that the variation in the degree of fiscal redistribution does not reflect differences in available resources. Moreover, controls for relative fiscal capacity also ensure that the indicators of the degree of fiscal redistribution do not capture the income effects associated with transfers. To allow for slow adjustment in tax policy, we also provide results of specifications conditional on the current tax rate. ${ }^{7}$

\footnotetext{
${ }^{6}$ The first preliminary account of equalization transfers for a budget year is typically published by the Federal Ministry of Finance in January of the next year. Detailed revenue forecasts for the current budget year are not available before the November when the federal forecast of tax revenues for the current year is issued.

7 Since the time dimension of the data covers a limited time period, accurate estimation of the adjustment speed may be difficult due to the Nickell (1981) bias. Since the cross-sectional dimension is also limited, however, we decided against using GMM methods that rely on large $\mathrm{n}$ asymptotics.
} 
As shown above, the degree of fiscal redistribution of RETT revenues is partly determined by local tax policies. To avoid potential biases, we employ instrumental variables. More specifically, we use as instrumental variables indicators of the degree of fiscal redistribution $\widehat{\beta}_{i, t}$ and $\hat{\rho}_{i, t}$ faced by state $i$ in period $t$ computed by counterfactual simulations, i.e. based on simulations that keep a state's tax rate and share of the tax base at pre-reform levels. In other words, as instrumental variables we use indicators of the degree of fiscal redistribution that a state would face if it had not used its newly assigned discretion to determine the rate and, thus, has kept the tax rate at the pre-reform level. To this end, we fix the state $i$ 's tax rate at the prereform level. Moreover, to avoid capturing indirect tax policy effects on the tax base, we also fix the state's share in the total tax base, $B_{i} / \sum B_{j}$, at the pre-reform level of the year 2006. Thus, the variation in the indicators used as instrumental variables results from changes in the fiscal equalization system independently of the tax policy in the respective state. Since the specification controls for relative fiscal capacity, $S_{i, t}^{p}$, income effects due to differences in revenues and equalization transfers are fully captured, and the instrumental variable should not exert any separate influence on tax policy, i.e. the exclusion restriction is unlikely to be violated.

\section{Data}

The empirical analysis examines the choice of the tax rate under fiscal capacity equalization. It explores how German states responded with their tax rates after they received the right to determine the rate of the RETT and, in particular, whether the tax policy response differs depending on the tax policy incentives associated with fiscal capacity equalization, as discussed in Sect. 2. The analysis explores the tax policy decisions of the states in the period from 2007 to $2017 .^{8}$ To identify differences in fiscal equalization, we exploit the institutional details of fiscal equalization among German states. Therefore, the next subsection provides a brief discussion of fiscal equalization. Subsequently, descriptive statistics on tax rates and indicators of fiscal redistribution are provided.

\subsection{Fiscal equalization in Germany}

The German system of fiscal equalization consists of different stages of vertical and horizontal distribution of funds. The first stage involves the distribution of VAT revenue shared between the federal and the state governments. The states' share is distributed mainly according to population size but a fraction is used to provide funds to states with below average per-capita revenues from own-source taxes. The second stage consists of a horizontal redistribution scheme. Transfers are paid to states with fiscal capacity (including VAT) below fiscal need and contributions are made by states with fiscal capacity above fiscal need. The fiscal

\footnotetext{
${ }^{8}$ The observation period covers 26 tax-rate changes. In 2018, no state changed the tax rate.
} 


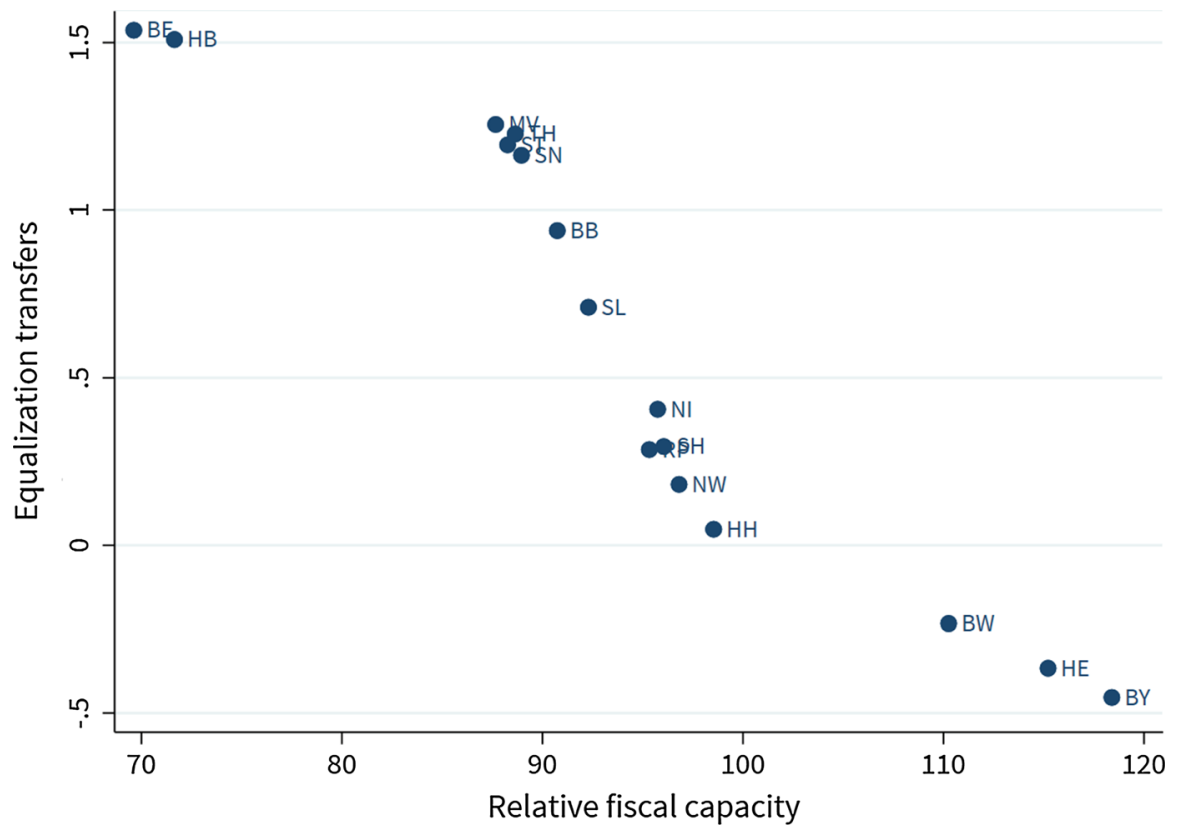

Fig. 2 Equalization Transfers and Relative Fiscal Capacity. Equalization transfers in 1,000 euros per capita. This includes the distribution of the VAT share (Ergaenzungsanteile) at the first stage, the horizontal transfer (Ausgleichszuweisungen/Ausgleichsbeitraege) at the second stage, as well as the federal transfers (Allgemeine Bundesergaenzungszuweisungen) at the third stage of fiscal equalization. Relative fiscal capacity is the fiscal capacity in \% of fiscal need according to the second stage of the fiscal equalization system. The authors' own computations based on data for 2016. BW = Baden-Wuerttemberg, BY $=$ Bavaria, $\mathrm{BE}=$ Berlin, $\mathrm{BB}=$ Brandenburg, $\mathrm{HB}=$ Bremen, $\mathrm{HH}=$ Hamburg, $\mathrm{HE}=$ Hesse, $\mathrm{MV}=\mathrm{Meck}-$ lenburg-West Pomerania, NI = Lower Saxony, NW = North Rhine-Westphalia, RP = Rhineland-Palatinate, $\mathrm{SL}=$ Saarland, SN = Saxony, ST = Saxony-Anhalt, SH = Schleswig-Holstein, $\mathrm{TH}=$ Thuringia

need is the population-weighted average of fiscal capacity across states. The third stage uses the same measure of fiscal capacity and provides further vertical transfers by the federal government to states with fiscal capacity below fiscal need.

At all stages, real estate transfer taxes are accounted for. Rather than using the revenues directly, the equalization system uses standardized tax revenues. The standardization involves applying the average tax rate, which is the weighted average of actual tax rates (see Eq. (1)), to the tax base of the real estate transfer tax.

Using data for 2016, Fig. 2 reports the indicator of fiscal capacity relative to fiscal need $\left(S_{i}\right)$ and the resulting level of transfers $\left(Z\left(S_{i}\right)\right)$ in per-capita terms.

As the figure shows, transfers are a decreasing function of relative fiscal capacity. The relationship between transfers and fiscal capacity is obviously non-linear. Three segments can be distinguished. A first segment shows high transfers and a limited degree of fiscal redistribution. An intermediate segment displays a stronger degree of redistribution and medium level of transfers. States with 
Table 1 Fiscal redistribution by state in 2006 and 2016

\begin{tabular}{|c|c|c|c|c|c|c|c|c|}
\hline \multirow[b]{4}{*}{ Year } & \multirow{4}{*}{$\begin{array}{l}\text { Popul. share } \\
2016\end{array}$} & \multirow{4}{*}{$\begin{array}{l}\text { Rel.fiscal capacity } \\
\left(S_{i}\right) \\
2016\end{array}$} & \multirow{2}{*}{\multicolumn{2}{|c|}{ Tax rate }} & \multicolumn{4}{|c|}{ Fiscal equalization } \\
\hline & & & & & \multirow{2}{*}{\multicolumn{2}{|c|}{$\frac{\text { Base effect }}{\left(\beta_{i}\right)}$}} & \multirow{2}{*}{\multicolumn{2}{|c|}{$\frac{\text { Rate effect }}{\left(\rho_{i}\right)}$}} \\
\hline & & & \multicolumn{2}{|l|}{$\left(\tau_{i}\right)$} & & & & \\
\hline & & & 2006 & 2016 & 2006 & 2016 & 2006 & 2016 \\
\hline State & (1) & (2) & (3) & (4) & $(5)$ & (6) & (7) & (8) \\
\hline Saxony & 4.97 & 88.95 & 3.5 & 3.5 & 0.95 & 1.40 & -0.02 & -0.01 \\
\hline Rhineland-Palatinate & 4.93 & 95.33 & 3.5 & 5.0 & 0.95 & 0.98 & -0.01 & -0.01 \\
\hline Berlin & 4.28 & 69.62 & 3.5 & 6.0 & 0.94 & 0.81 & 0.03 & 0.02 \\
\hline Schleswig-Holstein & 3.48 & 96.05 & 3.5 & 6.5 & 0.96 & 0.76 & 0.01 & 0.00 \\
\hline Brandenburg & 3.02 & 90.74 & 3.5 & 6.5 & 0.97 & 0.78 & -0.01 & -0.01 \\
\hline Saxony-Anhalt & 2.73 & 88.26 & 3.5 & 5.0 & 0.95 & 1.00 & -0.01 & -0.01 \\
\hline Thuringia & 2.64 & 88.64 & 3.5 & 5.0 & 0.97 & 1.00 & -0.02 & -0.02 \\
\hline Meckl.-West Pomerania & 1.96 & 87.67 & 3.5 & 5.0 & 0.98 & 1.01 & -0.01 & -0.00 \\
\hline Saarland & 1.21 & 92.29 & 3.5 & 6.5 & 0.98 & 0.78 & -0.00 & -0.00 \\
\hline Bremen & 0.82 & 71.65 & 3.5 & 5.0 & 0.93 & 1.02 & -0.00 & -0.00 \\
\hline Bavaria & 15.63 & 118.39 & 3.5 & 3.5 & 0.61 & 0.86 & 0.01 & 0.04 \\
\hline Baden-Wuerttemberg & 13.24 & 110.25 & 3.5 & 5.0 & 0.63 & 0.63 & 0.00 & 0.00 \\
\hline Hesse & 7.52 & 115.21 & 3.5 & 6.0 & 0.68 & 0.56 & 0.02 & 0.01 \\
\hline North Rhine-Westphalia & 21.74 & 96.81 & 3.5 & 6.5 & 0.42 & 0.62 & 0.01 & -0.02 \\
\hline Lower Saxony & 9.65 & 95.75 & 3.5 & 5.0 & 0.89 & 0.93 & -0.02 & -0.02 \\
\hline Hamburg & 2.18 & 98.54 & 3.5 & 4.5 & 0.72 & 0.99 & 0.01 & 0.01 \\
\hline
\end{tabular}

Population share and fiscal position (relative fiscal capacity) in \% obtained from the announcements of the fiscal equalization account by the Federal Ministry of Finance. Relative fiscal capacity defined as fiscal capacity (Finanzkraftmesszahl) relative to fiscal need (Ausgleichsmesszahl) in \%. Tax rates obtained from state announcements. Degree of fiscal redistribution $\beta_{i}$ for a state-specific shock in the tax base of the RETT (see Eq. 3) obtained by own simulation analysis. Degree of fiscal redistribution $\rho_{i}$ for a statespecific shock in the tax rate of the RETT (see Eq. 4) obtained by the authors' own simulation analysis

capacity above average fall into a third segment. It comprises states providing net contributions.

To compute indicators of the degrees of fiscal redistribution, we simulate the fiscal equalization scheme based on the full account of the various tax revenues collected by each of the states in each year. All three stages of fiscal equalization are taken into account. In terms of the above stylized model of fiscal equalization, the simulations provide us with values for $\beta_{i}$ and $\rho_{i}$ for each state in each year. To compute $\beta_{i}$ we consider the effect of a shock to the tax base of state $i$ on the transfers received by this state. The shock is scaled so as to generate a tax revenue increase by 1 million euros at the average tax rate. $\rho_{i}$ is obtained by considering the effects of a change in the tax rate of state $i$ by 1 percentage point.

Table 1 provides degrees of fiscal redistribution and other indicators by state in 2006 and 2016, at the beginning and end of the observation period, ordered by groups of states and population size. Columns (1) and (2) depict the population 
share and the relative fiscal capacity in 2016. Columns (3) and (4) show the tax rates in 2006 and 2016 of the respective state. Column (5) reports the degree of fiscal redistribution of a change in revenues due to the tax base $\left(\beta_{i}\right)$ based on the tax revenues in 2006, i.e. before the federal reform.

The majority of small states (Saxony, Rhineland-Palatinate, Berlin, SchleswigHolstein, Brandenburg, Saxony-Anhalt, Thuringia, Mecklenburg-West Pomerania, Saarland, Bremen) have relatively low fiscal capacity. For these states, the degree of fiscal redistribution $\left(\beta_{i}\right)$ is quite high in 2006. In all of these cases, the degree of redistribution is above 0.9. This indicates that a shock in the tax base of the real estate transfer tax generating one euro of additional tax revenues results in an increase in net funds for redistribution of less than 10 cents. In other words, if revenues increase by one euro, 90 cents of the increase are compensated for by a reduction in equalization transfers. A second group of states is relatively large and shows high levels of fiscal capacity (Bavaria, Baden-Wuerttemberg, Hesse). For these states the degree of fiscal redistribution is much lower, showing figures below 0.7. This indicates that a shock in the tax base of the real estate transfer tax generating one euro of additional tax revenue results in an increase in net funds for redistribution of more than 30 cents. A last group of states either is relatively large or has large fiscal capacity (North Rhine-Westphalia, Lower Saxony, Hamburg). Here the degree of fiscal redistribution varies but is lower than for the first group.

The figures for 2016 look much different (see Column (6)). Though the system of fiscal equalization is the same, for some states $\beta_{i}$ has increased, for others it has declined. It seems that the changes are mainly the consequence of changes in tax rates. States that have increased their tax rate the most, such as Berlin, Brandenburg and Saarland, face a decline in fiscal redistribution relative to 2006. The two states, that have not increased their tax rate, experience an increase in the degree of fiscal redistribution (Saxony and Bavaria). Most notably in Saxony the degree of fiscal redistribution is above 1 in 2016. With a degree of fiscal redistribution of about 1.40 , the state loses transfers for each euro of additional tax revenues amounting to 1.40 euros. Hence, at the margin, the state's revenues, net of transfers, decline by 40 cents with every additional euro of revenues from the real estate transfer tax. This extreme level of redistribution ${ }^{9}$ is not observed for any other state in 2016. However, Bremen and Mecklenburg-West Pomerania also show degrees of fiscal redistribution above 1 .

Columns (7) and (8) report the degree of fiscal redistribution of a change in revenues due to the tax rate (given the tax base) $\left(\rho_{i}\right)$ based on data for 2006 and 2016. It shows little variation and is in most cases very close to zero. This indicates that the fiscal redistribution of the mechanical revenue effect from a change in the tax rate is very small. Hence, the equalization rate effect is unimportant in the case of the German RETT.

Figure 3 depicts the evolution of the degree of fiscal redistribution of tax base effects over time. The figure reports the actual degree of fiscal redistribution of

\footnotetext{
9 The fact that there is more than $100 \%$ redistribution has been noted in the German debate, see, for instance, Fichte (2013), Boysen-Hogrefe (2017) and Buettner and Krause (2018).
} 


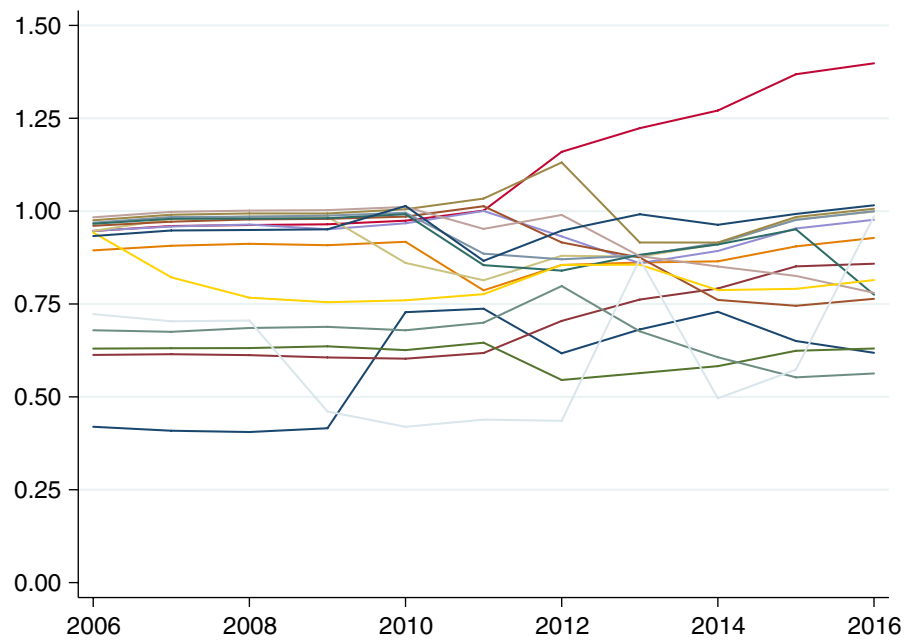

Fig. 3 Degree of Fiscal Redistribution (tax base $\beta$ ). Degree of fiscal redistribution of changes in revenues due to tax base changes $\beta_{i, t}$ for a state-specific shock in the tax base of the RETT (see Eq. 3 ) obtained by own simulation analysis. The data points for 2006 and 2016 are reported in Table 1

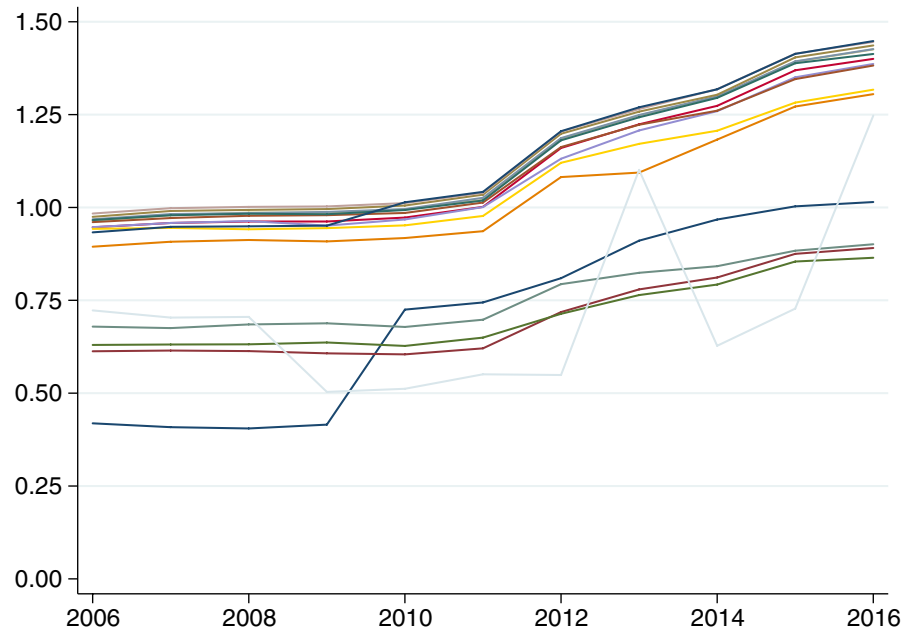

Fig. 4 Degree of Fiscal Redistribution (tax base $\beta$ ). Counterfactual Simulations. Degree of fiscal redistribution of changes in revenues due to tax base changes for a state-specific shock in the tax base of the RETT (see Eq. 3) obtained by simulations computed on the counterfactual assumption that tax rate and share of the tax base of the state under consideration have stayed constant at pre-reform levels

revenue effects of a shock in the tax base. Accordingly, in 2006 the degree of redistribution of a tax-base shock varies between 0.4 and 1 , and the mean and the variance of the degree of fiscal redistribution tend to increase over time.

While the actual degree of redistribution is affected by the state's own choice of the tax rate, Fig. 4 reports the development based on the counterfactual simulations. 
Table 2 Descriptive statistics

\begin{tabular}{llllll}
\hline Variables & Obs. & Mean & SD & Min & Max \\
\hline Tax rate & 176 & 4.247 & .8900 & 3.5 & 6.5 \\
Degree of fiscal redistribution (tax base $\beta$ ) & 176 & .8450 & .1801 & .4054 & 1.398 \\
$\quad$ Counterfactual simulation & 176 & .9925 & .2500 & .4050 & 1.448 \\
Degree of fiscal redistribution (tax rate $\rho$ ) & 176 & -.0009 & .0147 & -.0247 & .0431 \\
$\quad$ Counterfactual simulation & 176 & -.0006 & .0132 & -.0211 & .0261 \\
Relative fiscal capacity (in \%) & 176 & 94.07 & 13.12 & 67.13 & 124.3 \\
Own-source taxes (in 1000 euros per capita) & 176 & 1.384 & .5317 & .4986 & 2.955 \\
Population size (in millions) & 176 & 5.10 & 4.69 & 0.65 & 18.03 \\
Public debt (in 1000 euros per capita) & 176 & 9.607 & 6.614 & 1.587 & 35.34 \\
\hline
\end{tabular}

Tax rate of the real estate transfer tax across the 16 German states in \%. Tax rates obtained from state announcements. Degree of fiscal redistribution $\beta$ for a state-specific shock in the tax base of the RETT (see Eq. 3) obtained by the authors' own simulation analysis. Degree of fiscal redistribution $\rho$ for a statespecific shock in the tax rate of the RETT (see Eq. 4) obtained by the authors' own simulation analysis. Relative fiscal capacity defined as fiscal capacity (Finanzkraftmesszahl) relative to fiscal need (Ausgleichsmesszahl) in \%

These simulations are based on the assumption that the tax rate and the share in the tax base of the state under consideration have stayed constant at the pre-reform level. The distribution shows fewer fluctuations, but the degree of fiscal redistribution shows a clear positive trend for all states. During the observation period, if a state had not followed the trend and kept its tax rate unchanged, the degree of fiscal redistribution of tax base effects for this state has, on average, grown by about a third. This trend is mainly driven by the increase in the standard tax rate, which is used to compute the tax capacity. ${ }^{10}$

\subsection{Descriptive statistics}

Table 2 provides descriptive statistics for the tax rates and the two key variables of interest, i.e. the degrees of fiscal redistribution with regard to the tax base and the tax rate, as well as for control variables. The latter group includes the indicator of relative fiscal capacity and population size. The table also includes statistics for an indicator of the states' revenues from own-source taxes, which is used in the first stage of fiscal equalization. It is included in the subsequent analysis to test for confounding income effects that may arise at given relative fiscal capacity.

$\overline{10}$ The tax-base-weighted average of the tax rate increased from $3.5 \%$ in 2006 to $5.1 \%$ in 2017. 


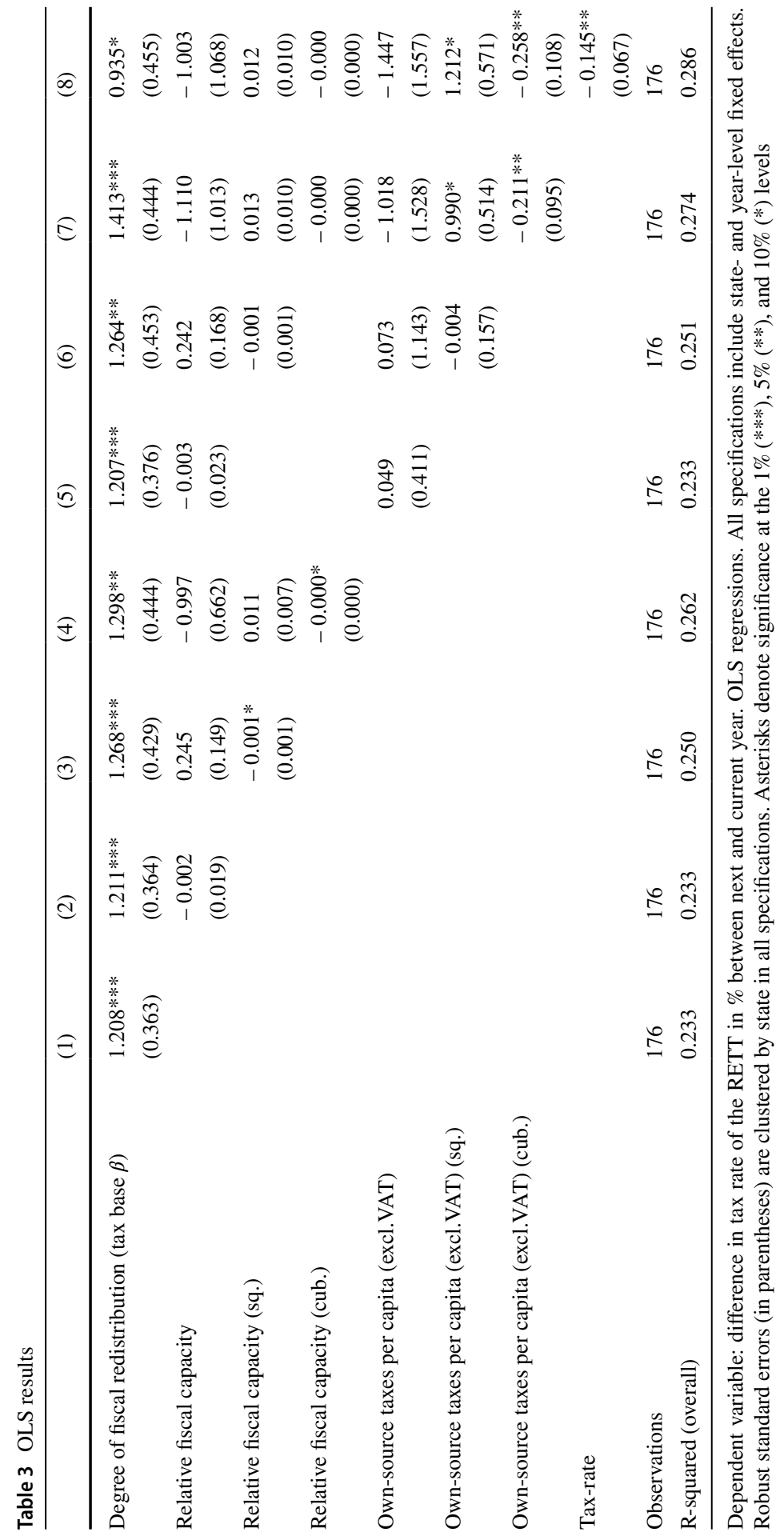




\section{Results}

Results from a basic set of OLS regressions are provided in Table 3. Given the very small degree of redistribution of revenue effects from tax rate changes $\left(\rho_{i}\right)$, it focuses on the redistribution of the tax base. Besides full sets of state-level and time-fixed effects, the first specification includes only the degree of fiscal redistribution $\left(\beta_{i}\right)$. It shows a positive effect. The next three specifications include indicators of the assignment variable, i.e. of relative fiscal capacity. Even though the higher-order terms improve the fit of the regression, the degree of fiscal redistribution exerts a similar effect on the tax policy. According to specifications (5) to (7), the positive effect of fiscal redistribution is robust against inclusion of revenues from own-source taxes (excluding VAT) per capita - an indicator that captures assignment in the first-stage of equalization. In order to allow for some adjustment in the tax rate in the first years after the devolution of the right for the states to set their own tax rate, Column (8) adds the current level of the tax rate. Hence, this specification considers tax policy for the upcoming period, conditional on the current choice of the tax rate. With this control added, the degree of fiscal redistribution is still found to exert a strong positive effect, but the effect turns out to be slightly smaller. This suggests that the effect of the actual degree of fiscal redistribution is confounded by the current tax policy.

Results from IV estimates are provided in Table 4. The estimations employ a measure of the degree of fiscal redistribution $\left(\hat{\beta}_{i}\right)$ as an instrumental variable that is based on counterfactual simulations. It captures the degree of redistribution faced by a state if its tax rate and the share of its tax base had stayed unchanged at pre-reform levels. For all specifications, the first-stage F-statistic for the excluded instrument provided at the bottom of the table indicates that the counterfactual simulation provides a strong predictor of the actual degree of fiscal redistribution. Compared with the OLS results, the results point to somewhat smaller effects of fiscal redistribution on tax policy.

Quantitatively, the point estimate provided by Column (7) suggests that in the presence of full fiscal redistribution of tax-base shocks $(\beta=1)$, the tax rate is about $1.3 \%$ percentage points higher when compared with a hypothetical situation where fiscal redistribution is absent $(\beta=0)$.

The analysis has focused on the redistribution of tax base effects. As a robustness check, Table 5 provides results of specifications that also include an indicator of the degree of fiscal redistribution associated with the tax rate effect. While the above findings are confirmed, no significant effects are found for this second indicator.

Since the specifications are conditional on the fiscal position of a state, the effect found for fiscal redistribution suggests that the remarkable series of tax increases after the reform in 2006 cannot be explained simply by a lack of funds but results from the incentive effect of fiscal redistribution. To test whether fiscal distress associated with the level of public debt may partly explain the tax policy, we have conducted further robustness checks where the level of public debt per capita is added as a control (see Table 6). Per-capita debt shows a small positive effect, which turns out to be estimated with substantial uncertainty and the estimates of the effect of fiscal redistribution show qualitatively similar effects to the above. 


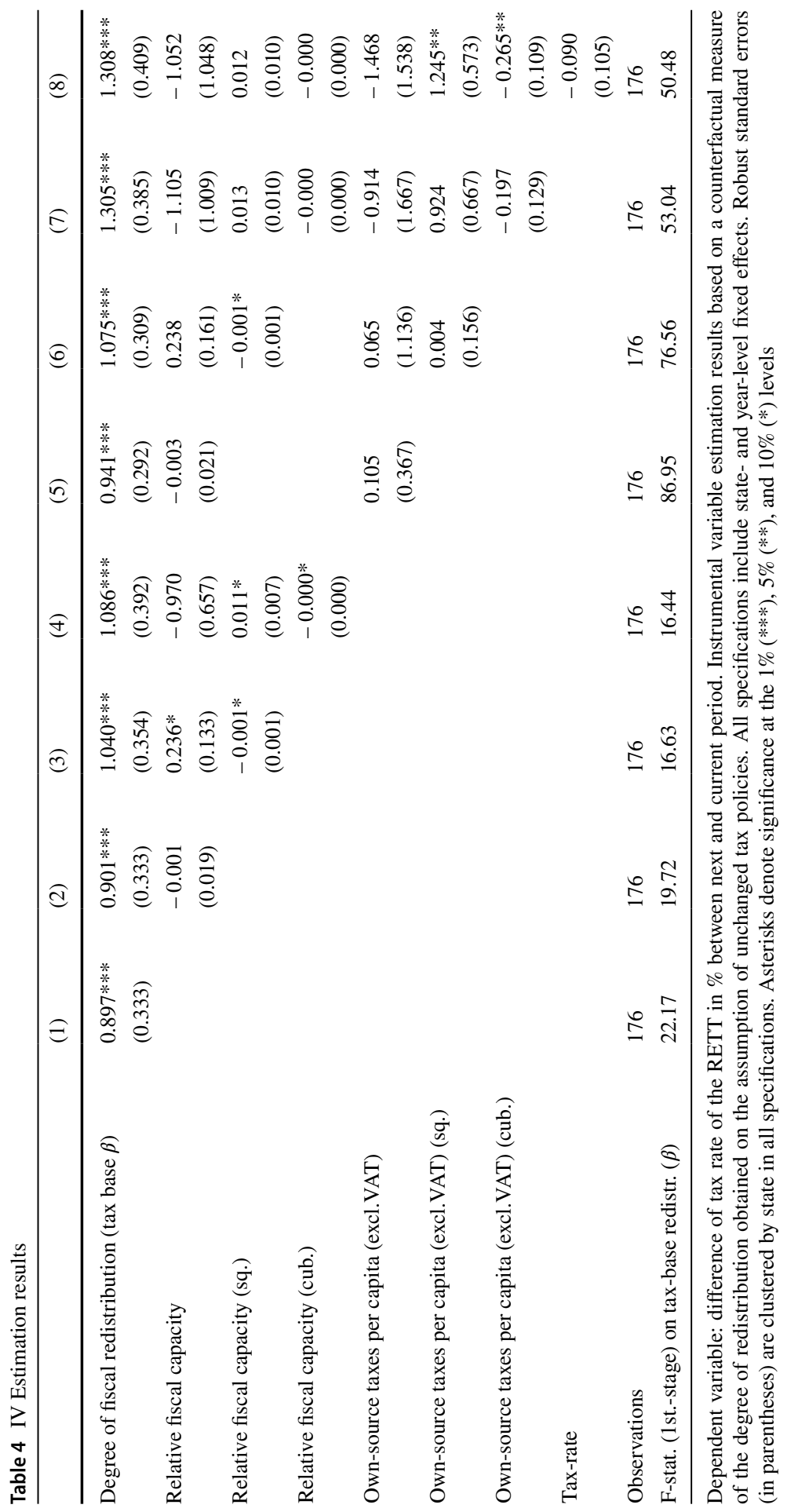




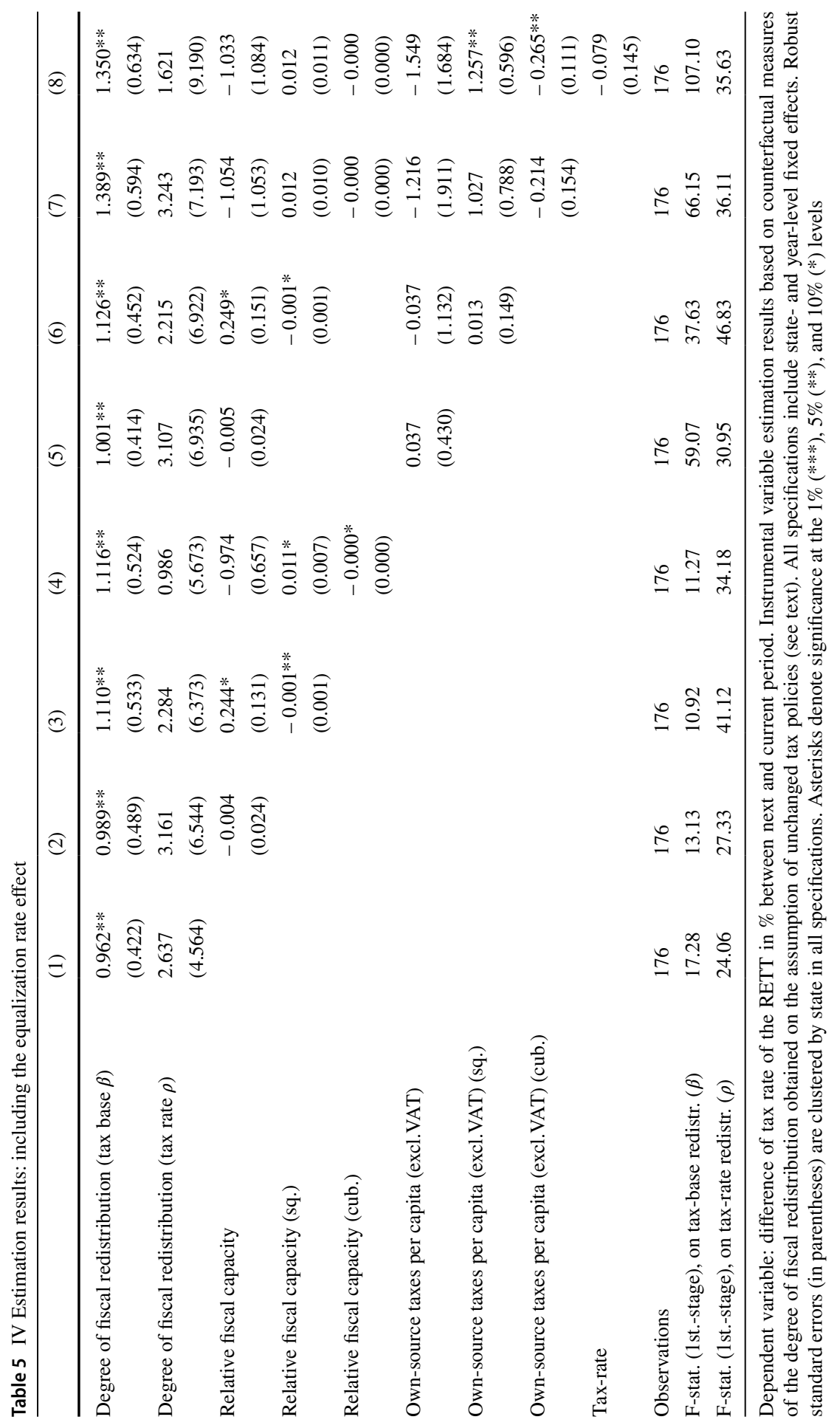




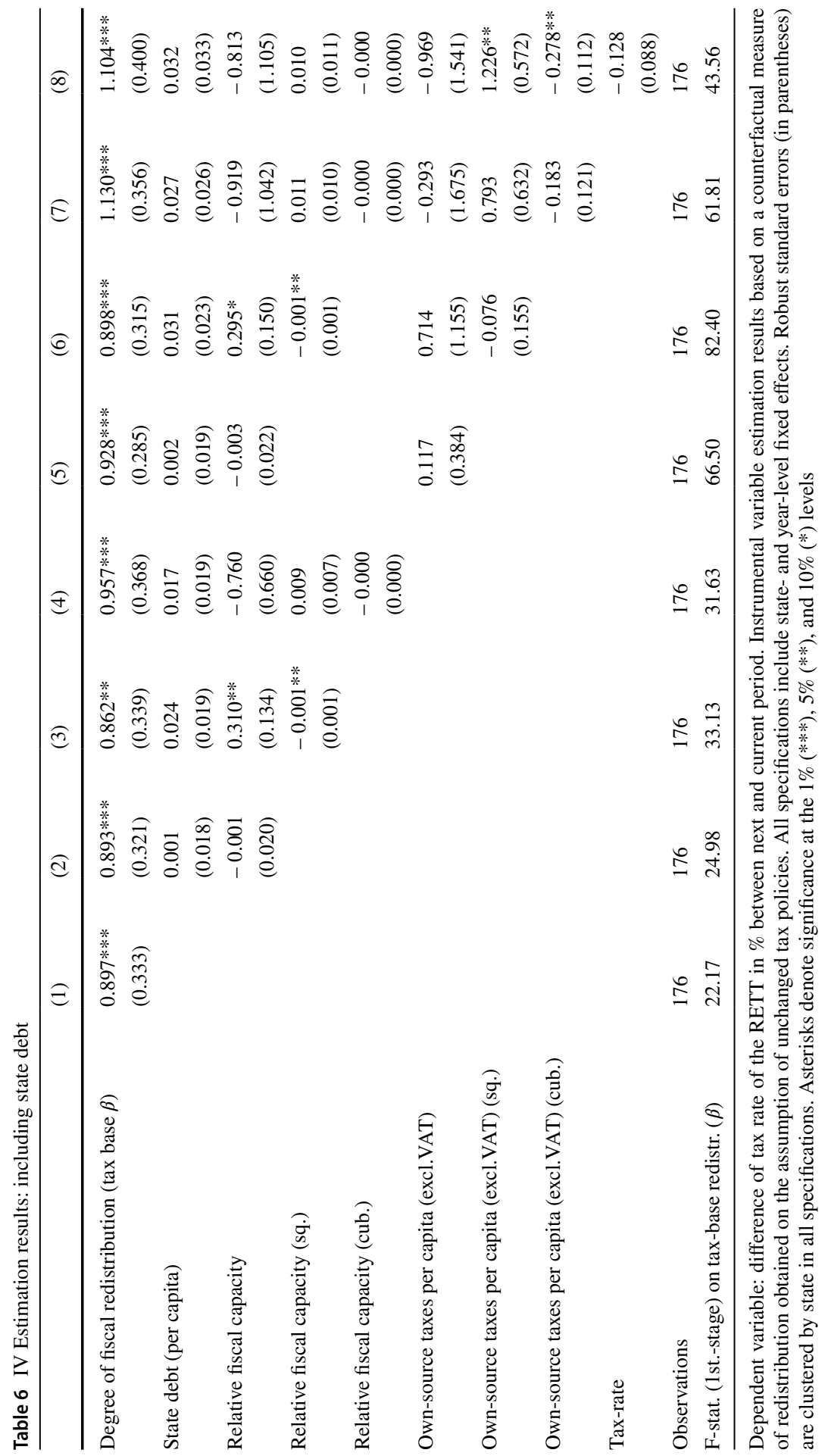




\section{Summary and conclusions}

This paper has explored the German states' tax policy response to a reform, which involves the devolution of taxing powers to the German states. More specifically, in 2007 German states obtained the right to choose the rate of the real estate transfer tax. This reform resulted in an unprecedented wave of tax increases. Among the 16 German states, within ten years after the reform no less than 26 tax increases occurred. No state lowered its tax rate. Initially, the tax rate was $3.5 \%$ on the sales price. In 2017, the mean tax rate was 5.3\%.

As we argue in the paper, due to a system of fiscal capacity equalization, the German states' tax policy is subject to strong incentives to increase the tax rates of the real estate transfer tax. Following Dahlby and Warren (2003), we identify two possible incentives for tax policy. The first incentive is associated with the effect of the tax rate on the tax base. Given the way fiscal capacity is defined, the adverse impact of a high tax rate on the tax base, which reflects the deadweight loss from taxation, contributes to a decline in fiscal capacity. Hence, a state that raises its tax rate receives more rather than less equalization transfers or, if it is a state with high fiscal capacity, needs to make lower transfers to other states. A second incentive effect can arise, since each state's tax policy decision is reflected in the average tax rate that is used by the equalization system to determine fiscal capacity.

We provide an empirical test of whether these incentive effects have led the states to increase their tax rate in the recent years. This test is based on a simulation analysis of the system of fiscal equalization which enables us to precisely compute the tax policy incentives faced by each state in each period. Our identification strategy exploits differences in the degree of fiscal redistribution among the states and over time. To distill the incentive effects empirically, we comprehensively control for income effects associated with tax capacity and transfers by including indicators of the relative fiscal capacity. To overcome possible confounding effects of the states' own policies on the incentive effects we use an instrumental variables approach. More specifically, we derive instrumental variables by means of counterfactual simulations that provide us with indicators of the degree of fiscal redistribution that keep a state's tax rate and its share of the tax base at pre-reform levels.

The results support strong effects of fiscal redistribution on tax policy. According to the point estimates, with full equalization of tax revenues, a state's tax rate for the real estate transfer tax is about 1.3 percentage points higher than without. This sizeable incentive effect is exclusively associated with the fiscal redistribution of the tax base. The equalization rate effect is unimportant in the German context.

Given that most German states faced substantial fiscal redistribution when the reform was implemented, the incentive provided by tax base equalization can explain a substantial part of the recent tax increases by German states. In addition, however, the basic incentive effect for states to raise their own tax rate has proliferated due to the equalization system. As states responded to the tax policy incentive by setting higher tax rates, the strength of the incentive faced by a state has been increasing over time. Hence, the first wave of tax increases raised the incentive to increase tax rates and thereby triggered further tax increases. 
Our findings point to the importance of the design of federal fiscal institutions. All federations need to find a balance between the autonomy of subnational governments and the goal to ensure that citizens in all regions have access to a certain level of public services. Autonomy requires subnational governments to have their own sources of revenue and some discretion in taxation. To meet the second objective, many federations provide fiscal transfers to subnational governments. As a consequence, local policies may change as governments can rely on both own-source and intergovernmental revenue to finance their expenditures. Our results show that the way intergovernmental revenue is determined in a system of fiscal capacity equalization induces subnational governments to increase rather than to reduce their own tax effort and set higher tax rates. Moreover, as capacity based equalization uses average tax rates to determine standardized tax revenues, subnational governments have an incentive to mimic other jurisdictions' tax policies. The German experience shows that the theoretical concerns about incentive effects of fiscal capacity equalization matter in practice. As a result of the federal reform, which granted the states the right to set the tax rate of the real estate transfer tax, the states' revenue structure has changed. The states now rely much more on a tax, which the public finance literature considers to be a highly distortionary revenue instrument.

\section{Data sources and definitions}

Population size: The population size is the total population in each state on June 30 of each year. Source: Federal Ministry of Finance (Annual announcements of the fiscal equalization account, (Zweite Verordnung zur Durchführung des Finanzausgleichsgesetzes, various years)).

Tax rate of the real estate transfer tax (in \%): The tax rate is the rate of the real estate transfer tax in percent applicable to property transactions. In cases where the tax rate has been changed within a year, the annual figure is interpolated based on the exact calendar days. Source: announcements by the 16 German states.

Tax base of the real estate transfer tax (in 1000 euros): The tax base of the real estate transfer tax is basically the sale price of the property. Source: Federal Ministry of Finance (Annual announcements of the fiscal equalization account, (Zweite Verordnung zur Durchführung des Finanzausgleichsgesetzes, various years)).

Relative fiscal capacity: Relative fiscal capacity is defined as fiscal capacity relative to fiscal need for each state. Fiscal capacity is defined as available revenues including state's own tax revenues, the share of income taxes, the VAT share and municipal tax revenues. Fiscal need is the population-weighted average of fiscal capacity across states. Source: Federal Ministry of Finance (Annual announcements of the fiscal equalization account, (Zweite Verordnung zur Durchführung des Finanzausgleichsgesetzes, various years)) and the authors' own calculations.

Own-source taxes per capita (excl.VAT): Revenues from own-source taxes per capita, standardized and excluding revenues from VAT per capita. This variable is used in the first stage of the equalization system to determine the VAT distribution. Source: Federal Ministry of Finance (Annual announcements of the fiscal equalization account, (Zweite Verordnung zur Durchführung des Finanzausgleichsgesetzes, various years)) and own calculations. 
Degree of fiscal redistribution (tax base $\beta$ ): The degree of fiscal redistribution captures the fraction of an increase in revenues due to a higher tax base that is compensated for through lower transfers. The state-specific shock in the tax base of the RETT is scaled so as to generate a tax revenue increase by 1 million euros at the average tax rate in all states and periods. Source: authors' own simulation analysis.

Degree of fiscal redistribution (tax rate $\rho$ ): The degree of fiscal redistribution captures the fraction of an increase in revenues due to a higher tax rate (at a given tax base) that is compensated for through lower transfers. The state-specific shock in the tax rate of the RETT is an increase of 1 percentage point. Source: authors' own simulation analysis.

Counterfactual degree of fiscal redistribution (tax base $\hat{\beta}$ ): The counterfactual degree of fiscal redistribution captures the fraction of an increase in revenues due to a higher tax base that is compensated for through lower transfers. It is calculated on the assumption that the respective state's tax rate and its share of the total tax base have remained at the pre-reform level in the year 2006. The state-specific shock in the tax base of the RETT is scaled so as to generate a tax revenue increase of 1 million euros at the average tax rate. Source: authors' own simulation analysis.

Counterfactual degree of fiscal redistribution (tax rate $\hat{\rho}$ ): The counterfactual degree of fiscal redistribution captures the fraction of an increase in revenues due to a higher tax rate that is compensated for through lower transfers. It is calculated under the assumption that the respective state's tax rate and its share of the total tax base have remained at the pre-reform level in the year 2006. The state-specific shock in the tax rate of the RETT is an increase in the tax rate of 1 percentage point. Source: authors' own simulation analysis.

Public debt per capita (in 1000 euros): Public debt per capita is the total level of state debt held by private and public sectors in 1000 euros measured in per-capita terms. Source: Federal Statistical Office.

Acknowledgements Open Access funding provided by Projekt DEAL.

Open Access This article is licensed under a Creative Commons Attribution 4.0 International License, which permits use, sharing, adaptation, distribution and reproduction in any medium or format, as long as you give appropriate credit to the original author(s) and the source, provide a link to the Creative Commons licence, and indicate if changes were made. The images or other third party material in this article are included in the article's Creative Commons licence, unless indicated otherwise in a credit line to the material. If material is not included in the article's Creative Commons licence and your intended use is not permitted by statutory regulation or exceeds the permitted use, you will need to obtain permission directly from the copyright holder. To view a copy of this licence, visit http://creativecommons.org/licen ses/by/4.0/.

\section{References}

Adam, S., Besley, T., Blundell, R., Bond, S., Chote, R., Gammie, M., Mirrlees, J., Johnson, P., Myles, G., \& Poterba, J. M. (2011). The Taxation of Land and Property. In Mirrlees, J. et al. (Eds.), Tax by Design-The Mirrlees Review. Oxford.

Baretti, C., Huber, B., \& Lichtblau, K. (2002). A tax on tax revenue-The incentive effects of equalizing transfers: Evidence from Germany. International Tax and Public Finance, 9(6), 631-649.

Boadway, R. (2004). The theory and practice of equalization. CESifo Economic Studies, 50(1), 211-254. 
Boenke, T., Joachimsen, B., \& Schroeder, C. (2015). Fiscal federalism and tax enforcement. German Economic Review, 18(3), 377-409.

Boysen-Hogrefe, J. (2017). Grunderwerbsteuer im Länderfinanzausgleich: Umverteilung der Zusatzlast der Besteuerung. Wirtschaftsdienst, 97(5), 354-359.

Bucovetsky, S., \& Smart, M. (2006). The efficiency consequences of local revenue equalization: Tax competition and tax distortions. Journal of Public Economic Theory, 8(1), 119-144.

Buettner, T. (2006). The incentive effect of fiscal equalization transfers on tax policy. Journal of Public Economics, 90(3), 477-497.

Buettner, T., \& Krause, M. (2018). Föderalismus im Wunderland: Zur Steuerautonomie bei der Grunderwerbsteuer. Perspektiven der Wirtschaftspolitik, 19(1), 32-41.

Dachis, B., Duranton, G., \& Turner, M. A. (2011). The effects of land transfer taxes on real estate markets: Evidence from a natural experiment in Toronto. Journal of Economic Geography, 12(2), 327-354.

Dahlby, B., \& Warren, N. (2003). Fiscal incentive effects of the Australian equalisation system. Economic Record, 79, 434-445.

Egger, P., Koethenbuerger, M., \& Smart, M. (2010). Do fiscal transfers alleviate business tax competition? Evidence from Germany. Journal of Public Economics, 94(3), 235-246.

Ferede, E. (2017). The incentive effects of equalization grants on tax policy: Evidence from Canadian provinces. Public Finance Review, 45(6), 723-747.

Fichte, D. (2013). Grunderwerbsteuer und Länderfinanzausgleich: Anreize für Steuererhöhungen beseitigen. DSi kompakt 2, DSi: Berlin.

Keen, M., \& Konrad, K. A. (2013). The theory of international tax competition and coordination. Handbook of Public Economics, 5, 257-297.

Keen, M. J., \& Kotsogiannis, C. (2002). Does federalism lead to excessively high taxes? American Economic Review, 92(1), 363-370.

Koethenbuerger, M. (2002). Tax competition and fiscal equalization. International Tax and Public Finance, 9(4), 391-408.

Krause, M., \& Potrafke, N. (2019). The real estate transfer tax and government ideology: Evidence from the German states. FinanzArchiv: Public Finance Analysis, 76(1), 100-120.

Lundborg, P., \& Skedinger, P. (1999). Transaction taxes in a search model of the housing market. Journal of Urban Economics, 45(2), 385-399.

Musgrave, R. A. (1961). Approaches to a fiscal theory of political federalism. In NBER (Ed.), Public Finances: Needs, sources, and utilization, (pp. 97-134). Princeton.

Nickell, S. (1981). Biases in dynamic models with fixed effects. Econometrica, 49(6), 1417-1426.

Rauch, A., \& Hummel, C. A. (2016). How to stop the race to the bottom. International Tax and Public Finance, 23(5), 911-933.

Smart, M. (1998). Taxation and deadweight loss in a system of intergovernmental transfers. Canadian Journal of Economics,. https://doi.org/10.2307/136384.

Smart, M. (2007). Raising taxes through equalization. Canadian Journal of Economics, 40(4), 1188-1212.

Wildasin, D. E. (1989). Interjurisdictional capital mobility: Fiscal externality and a corrective subsidy. Journal of Urban Economics, 25, 193-212.

Wilson, J. D. (1999). Theories of tax competition. National Tax Journal, 52, 269-304.

Publisher's Note Springer Nature remains neutral with regard to jurisdictional claims in published maps and institutional affiliations. 